\title{
FEATURES OF PLANTAR PRESSURE DISTRIBUTION OF CHINESE CHILDREN AGED BETWEEN TWO AND ELEVEN
}

\section{CARACTERISTICI ALE DISTRIBUTIEI PRESIUNII PLANTARE LA COPIII CU VÂRSTA ÎNTRE DOI ŞI UNSPREZECE ANI DIN CHINA}

\author{
Jin $\mathrm{ZHOU}^{1,2}$, Ying SONG ${ }^{1}$, Bo XU ${ }^{1}$, Wuyong $\mathrm{CHEN}^{1,2^{*}}$ \\ ${ }^{1}$ National Engineering Laboratory for Clean Technology of Leather Manufacture, Sichuan University, Chengdu 610065, P. R. China, e-mail: \\ zj_scu@qq.com, wuyong.chen@163.com
}

${ }^{2}$ Key Laboratory for Leather Chemistry and Engineering of the Education Ministry, Sichuan University, Chengdu 610065, P. R. China

\begin{abstract}
FEATURES OF PLANTAR PRESSURE DISTRIBUTION OF CHINESE CHILDREN AGED BETWEEN TWO AND ELEVEN
ABSTRACT. Since foot biomechanics of Chinese healthy children has not been systematically investigated, the aim of this study was to comprehend the features of plantar pressure distribution of those subjects. Totally, 895 healthy children aged between two and 11 were recruited and those with the foot deformities were excluded by visual inspection. Children's plantar pressure was measured by Footscan pressure plate with two-step protocol and self-selected speed. Regions of plantar pressure were divided into ten parts: hallux, toes 2-5, the first to fifth metatarsal head, mid foot, medial heel and lateral heel, at which parameters of peak pressure $\left(\mathrm{N} / \mathrm{cm}^{2}\right)$, relative pressure time integral (\%) and relative contact area (\%) were calculated. Error-bar plot was drawn to interpret the change of plantar pressure with the age. Moreover, the reliability of this study was evaluated by intra-class correlation and coefficient of variance with the significance level of 0.05 and confidence interval of $95 \%$. Our outcomes show that plantar pressure was generally increasing with the foot development in the most foot regions, except mid foot area; further, significant gender differences existed in a few regions and for boys a higher pressure and a larger contact area were recorded. At last, results of all three parameters were recorded with moderate to good reliability and the reliability of all variables was improving with the age. Overall, our study provided a normative plantar pressure distribution of healthy Chinese children and those findings could be used in clinical abnormal feet evaluation.
\end{abstract}

KEY WORDS: Chinese children, plantar pressure, gender differences, children's development

\section{CARACTERISTICI ALE DISTRIBUTIEI PRESIUNII PLANTARE LA COPIII CU VÂRSTA ÎNTRE DOI ȘI UNSPREZECE ANI DIN CHINA}

REZUMAT. Întrucât biomecanica piciorului la copiii sănătoşi din China nu s-a investigat sistematic până acum, scopul acestui studiu a fost acela de a înţelege caracteristicile distribuţiei presiunii plantare la aceşti subiecţi. S-au recrutat în total 895 de copii sănătoşi cu vârsta cuprinsă între doi şi unsprezece ani, excluzânduse pe baza inspecţiei vizuale cei cu diformităţi la nivelul picioarelor. Presiunea plantară la copii a fost măsurată cu ajutorul plăcii de presiune Footscan utilizând un protocol în doi paşi şi o viteză auto-selectată. Regiunile presiunii plantare au fost împărţite în zece părţi: halucele, degetele 2-5, zona de la primul la cel de-al cincilea cap metatarsian, zona mediană a piciorului, partea de mijloc a călcâiului, părţile laterale ale călcâiului, regiuni în care s-au calculat parametri precum presiunea maximă $\left(\mathrm{N} / \mathrm{cm}^{2}\right)$, integrala relativă presiune-timp (\%) şi zona relativă de contact (\%). S-a realizat diagrama cu bare de eroare pentru a interpreta modificarea presiunii plantare odată cu vârsta. Mai mult decât atât, fiabilitatea acestui studiu a fost evaluată prin corelarea intraclasă şi coeficientul de varianţă cu nivel de semnificaţie de 0,05 şi interval de încredere de $95 \%$. Rezultatele noastre indică faptul că presiunea plantară a crescut, în general, odată cu dezvoltarea piciorului, în majoritatea regiunilor, cu excepţia zonei mediane a piciorului; în plus, au existat câteva diferenţe semnificative între sexe în câteva regiuni, la băieţi înregistrându-se o presiune mai ridicată şi o zonă de contact mai mare. În cele din urmă, rezultatele tuturor celor trei parametri au fost înregistrate cu fiabilitate moderată spre bună, iar fiabilitatea tuturor variabilelor s-a îmbunătăţit cu vârsta. Per ansamblu, studiul nostru a oferit o distribuţie normativă a presiunii plantare la copiii sănătoşi din China, iar rezultatele obţinute ar putea fi utilizate la evaluarea clinică a picioarelor cu probleme.

CUVINTE CHEIE: copii din China, presiune plantară, diferenţe între sexe, dezvoltarea copiilor

LES CARACTÉRISTIQUES DE LA DISTRIBUTION DE PRESSION PLANTAIRE CHEZ LES ENFANTS CHINOIS ÂGÉS DE DEUX À ONZE ANS

RÉSUMÉ. Étant donné que la biomécanique du pied chez les enfants chinois en bonne santé n'a pas été étudiée systématiquement à ce jour, l'objectif de cette étude était de comprendre les caractéristiques de la distribution des pressions plantaires chez ces sujets. On a recruté un total de 895 enfants en bonne santé âgés de deux à onze ans, en excluant par l'inspection visuelle ceux avec des malformations dans les pieds. La pression plantaire chez les enfants a été mesurée en utilisant la plaque de pression Footscan à l'aide d'un protocole en deux étapes et une vitesse auto-sélectionnée. Les régions de pression plantaire ont été réparties en dix parties : le hallux, les doigts 2-5, la région de la première à la cinquième tête métatarsienne, le milieu du pied, le milieu du talon, les côtés du talon, les régions dans lesquelles on a calculé les paramètres tels que le pic de pression (N/ $\left.\mathrm{cm}^{2}\right)$, l'intégrale relative pression-temps (\%) et la surface de contact relative (\%). On a établi la diagramme à barre d'erreur pour interpréter le changement de pression plantaire avec l'âge. En outre, la fiabilité de cette étude a été évaluée par la corrélation intra-classe et par le coefficient de la variance avec un niveau de signification de 0,05 et l'intervalle de confiance à $95 \%$. Nos résultats indiquent que la pression plantaire a augmenté, en général, avec le développement du pied, dans la plupart des régions, à l'exception du point médian du pied; en outre, il y avait plusieurs différences importantes entre les sexes dans certaines régions : les garçons ont enregistré une pression plus élevée et une surface de contact plus grande. Enfin, les résultats de ces trois paramètres ont été enregistrés à fiabilité modérée à bonne, et la fiabilité de toutes les variables est améliorée avec l'âge. Dans l'ensemble, notre étude a fourni une répartition normative de la pression plantaire chez les enfants chinois en bonne santé, et les résultats pourraient être utilisés dans l'évaluation clinique des problèmes du pied.

MOTS CLÉS: enfants chinois, pression plantaire, différences entre les sexes, développement des enfants

* Correspondence to: Wuyong CHEN, National Engineering Laboratory for Clean Technology of Leather Manufacture, Sichuan University Chengdu 610065, P. R. China, Fax: 86-28-85405237, e-mail: wuyong.chen@163.com 


\section{INTRODUCTION}

Children's foot structure develops dramatically since their birth. Two phases are significantly observed in their childhood [1-3]: one is from the time of independent walking to the age of six, where foot arch grows quickly and it plays a main role in the walking event [2]; the other is between the ages of six to ten, in which the step length and stride increase prominently, so as to reduce the stride frequency and make the walking speed more stable [4,5]. Those significant changes imply that the foot is of high plasticity and it can be easily influenced by external factors, such as obesity [6], nutritional status, family genetic disease [7], etc. Thereby, comprehending the law of children's foot development and their biomechanics features is critical.

Since the plantar pressure is one of the windows to inspect the foot condition and it was reported with good repeatability and reliability $[2,8]$, this approach has been widely used in study of children's foot and foot disease examination [9]. Currently, two types of literature were reported: the cross-sectional study and the longitudinal one. In terms of longitudinal study $[10,11]$, plantar pressure distribution of healthy German children aged between 13 and 128 months was investigated and a normative plantar pressure of that population was established. Similarly, Hallemans et al. [2] were focusing on children's foot development within the period of five months since independent walking. In terms of cross-sectional study, Alvarez et al. [12] studied plantar pressure distribution of 146 children aged between 1.6 to 14.9 and Henning et al. [13] investigated those of 125 healthy children aged between six and ten. Although based on the above research, features of plantar pressure of healthy children have been interpreted, according to the study of Phyllis [7], variation existed in children's growth in different countries; therefore, investigation of the plantar pressure of Chinese children is necessary and those outcomes could be used for the interpretation of the foot development of healthy Chinese children.

Hence, the aim of this study was to measure the plantar pressure of 895 healthy children aged between two and 11 and then to comprehend the features of plantar pressure distribution of Chinese children.

\section{INTRODUCERE}

Structura piciorului la copii se dezvoltă dramatic de la naşterea acestora. Se observă cu precădere două faze în copilăria acestora [1-3]: prima cuprinsă între momentul în care încep să meargă independent şi vârsta de şase ani, când bolta piciorului creşte rapid şi joacă un rol principal în cadrul mersului [2]; a doua este cea cuprinsă între şase şi zece ani, când lungimea pasului creşte vizibil, pentru a reduce frecvenţa paşilor şi pentru a stabiliza mersul $[4,5]$. Acele modificări semnificative presupun o mare plasticitate a piciorului, care poate fi influenţat cu uşurinţă de factori externi precum obezitatea [6], starea de nutriţie, bolile genetice [7] etc. Prin urmare, înţelegerea legii care stă la baza dezvoltării picioarelor la copii şi caracteristicile biomecanice ale acestora este critică.

Întrucât presiunea plantară constituie o metodă repetabilă şi fiabilă $[2,8]$ de a examina starea piciorului, această abordare a fost utilizată pe scară largă în studiul picioarelor şi în analiza afecţiunilor la nivelul picioarelor copiilor [9]. În prezent, literatura raportează două tipuri de studii: studiul transversal şi cel longitudinal. În ceea ce priveşte studiul longitudinal $[10,11]$, s-a investigat distribuţia presiunii plantare la copii sănătoşi din Germania, cu vârsta cuprinsă între 13 şi 128 de luni şi sa stabilit o presiune plantară normativă pentru acel segment de populaţie. În mod similar, Hallemans şi colab. [2] s-au axat pe dezvoltarea piciorului la copii într-o perioadă de cinci luni de la începutul stadiului de mers independent. În ceea ce priveşte studiul transversal, Alvarez şi colab. [12] au studiat distribuţia presiunii plantare la 146 de copii cu vârsta cuprinsă între 1.6 şi 14.9 ani, iar Henning şi colab. [13] au investigat acelaşi lucru la 125 de copii sănătoşi cu vârsta cuprinsă între şase şi zece ani. Deşi, pe baza studiilor menţionate mai sus s-au interpretat caracteristicile presiunii plantare la copii sănătoşi, potrivit studiului efectuat de Phyllis [7], a existat o variaţie în dezvoltarea copiilor în diferite ţări; prin urmare, investigarea presiunii plantare la copiii din China este necesară şi rezultatele obţinute pot fi utilizate pentru a interpreta dezvoltarea picioarelor la copiii sănătoşi din China.

Prin urmare, scopul acestui studiu a fost de a măsura presiunea plantară la un număr de 895 de copii sănătoşi cu vârsta cuprinsă între doi şi 11 ani şi apoi de a înţelege caracteristicile distribuţiei presiunii plantare la copiii din China. 


\section{MATERIALS AND METHODS}

\section{Subjects}

Totally, 895 health children aged between two and 11 were recruited and those with the foot deformities were excluded by visual inspection from an experienced clinical expert. Their mean age is $7.7 \pm$ 2.2 years, mean height is $126.2 \pm 16.0 \mathrm{~cm}$, mean weight is $27.8 \pm 9.0 \mathrm{Kg}$ and gender ratio is 448 male / 447 female. Demographic information of all subjects in each age group was shown in Table 1 . Before the measurement, aims and procedures of this study were explained to the children's parent and their formal agreements have been given. Further, this study followed the requirement of "Declaration of Helsinki" and was confirmed by the ethics committee of the university.

\section{MATERIALE ŞI METODE}

\section{Subiecţi}

S-au recrutat în total 895 de copii sănătoşi cu vârsta cuprinsă între doi şi 11 ani, iar cei cu diformităţi la nivelul picioarelor au fost excluşi pe baza inspecţiei vizuale efectuate de un specialist cu experienţă. Vârsta lor medie a fost de $7,7 \pm 2,2$ ani, înălţimea medie a fost de $126,2 \pm 16,0 \mathrm{~cm}$, greutatea medie a fost de $27,8 \pm 9,0$ Kg, iar raportul între sexe a fost 448 de băieţi / 447 fete. Datele demografice ale tuturor subiecţilor din fiecare grupă de vârstă sunt prezentate în Tabelul 1. Înainte de a efectua măsurătorile, li s-au explicat părinţilor scopul şi procedurile utilizate în studiu, iar aceştia şi-au dat acordul oficial. În plus, acest studiu a urmat principiile "Declaraţiei de la Helsinki" şi a fost aprobat de comisia de etică a universităţii.

Table 1: Demographic information of all subjects in each age group Tabelul 1: Date demografice ale tuturor subiecţilor din fiecare grupă de vârstă

\begin{tabular}{|c|c|c|c|c|c|c|c|c|c|c|c|c|c|c|c|}
\hline \multirow{2}{*}{$\begin{array}{l}\text { Demographic } \\
\text { information } \\
\text { Date } \\
\text { demografice }\end{array}$} & \multicolumn{3}{|c|}{$\begin{array}{l}\text { Age } 2 \\
2 \text { ani }\end{array}$} & \multicolumn{3}{|c|}{$\begin{array}{l}\text { Age } 3 \\
3 \text { ani }\end{array}$} & \multicolumn{3}{|c|}{$\begin{array}{l}\text { Age } 4 \\
4 \text { ani }\end{array}$} & \multicolumn{3}{|c|}{$\begin{array}{l}\text { Age } 5 \\
5 \text { ani }\end{array}$} & \multicolumn{3}{|c|}{$\begin{array}{l}\text { Age } 6 \\
6 \text { ani }\end{array}$} \\
\hline & $\mathrm{n}$ & $\begin{array}{l}\text { Mean } \\
\text { Medie }\end{array}$ & $\begin{array}{c}\text { SD } \\
\text { Abatere } \\
\text { standard }\end{array}$ & $\mathrm{n}$ & $\begin{array}{l}\text { Mean } \\
\text { Medie }\end{array}$ & $\begin{array}{c}\text { SD } \\
\text { Abatere } \\
\text { standard }\end{array}$ & $n$ & $\begin{array}{l}\text { Mean } \\
\text { Medie }\end{array}$ & $\begin{array}{c}\text { SD } \\
\text { Abatere } \\
\text { standard }\end{array}$ & $n$ & $\begin{array}{l}\text { Mean } \\
\text { Medie }\end{array}$ & $\begin{array}{c}\text { SD } \\
\text { Abatere } \\
\text { standard }\end{array}$ & $n$ & $\begin{array}{l}\text { Mean } \\
\text { Medie }\end{array}$ & $\begin{array}{c}\text { SD } \\
\text { Abatere } \\
\text { standard }\end{array}$ \\
\hline $\begin{array}{c}\text { Age } \\
\text { Vârstă }\end{array}$ & 9 & 2.6 & 0.5 & 59 & 3.6 & 0.2 & 56 & 4.5 & 0.3 & 53 & 5.3 & 0.3 & 142 & 6.4 & 0.4 \\
\hline $\begin{array}{l}\text { Height } \\
\text { Inălţime }\end{array}$ & 9 & 97.1 & 14.3 & 59 & 98.4 & 6.4 & 56 & 102.0 & 7.0 & 53 & 107.1 & 4.8 & 142 & 119.0 & 5.7 \\
\hline $\begin{array}{l}\text { Weight } \\
\text { Greutate }\end{array}$ & 9 & 16.3 & 4.3 & 59 & 16.5 & 2.2 & 56 & 17.4 & 2.8 & 53 & 18.7 & 2.9 & 142 & 23.3 & 4.1 \\
\hline \multirow[t]{2}{*}{$\begin{array}{c}\text { Sex (Boy/Girl) } \\
\text { Sex (băiat/fată) }\end{array}$} & \multicolumn{3}{|c|}{$4 / 5$} & \multicolumn{3}{|c|}{$29 / 30$} & \multicolumn{3}{|c|}{$29 / 27$} & \multicolumn{3}{|c|}{$30 / 23$} & \multicolumn{3}{|c|}{$73 / 69$} \\
\hline & \multicolumn{3}{|c|}{$\begin{array}{l}\text { Age } 7 \\
7 \text { ani }\end{array}$} & \multicolumn{3}{|c|}{$\begin{array}{l}\text { Age } 8 \\
8 \text { ani }\end{array}$} & \multicolumn{3}{|c|}{$\begin{array}{l}\text { Age } 9 \\
9 \text { ani }\end{array}$} & \multicolumn{3}{|c|}{$\begin{array}{l}\text { Age } 10 \\
10 \text { ani }\end{array}$} & \multicolumn{3}{|c|}{$\begin{array}{l}\text { Age } 11 \\
11 \text { ani }\end{array}$} \\
\hline $\begin{array}{l}\text { Age } \\
\text { Vârstă }\end{array}$ & 98 & 7.3 & 0.4 & 175 & 8.3 & 0.3 & 106 & 9.2 & 0.3 & 104 & 10.2 & 0.3 & 93 & 11.1 & 0.1 \\
\hline $\begin{array}{l}\text { Height } \\
\text { Înălţime }\end{array}$ & 98 & 124.7 & 5.2 & 175 & 130.0 & 6.2 & 106 & 135.7 & 6.1 & 104 & 142.4 & 7.1 & 93 & 147.6 & 6.5 \\
\hline $\begin{array}{l}\text { Weight } \\
\text { Greutate }\end{array}$ & 98 & 25.4 & 4.7 & 175 & 28.8 & 5.9 & 106 & 32.0 & 5.8 & 104 & 36.5 & 7.0 & 93 & 40.2 & 7.1 \\
\hline $\begin{array}{c}\text { Sex (Boy/Girl) } \\
\text { Sex (băiat/fată) }\end{array}$ & \multicolumn{3}{|c|}{$46 / 52$} & \multicolumn{3}{|c|}{$82 / 93$} & \multicolumn{3}{|c|}{$52 / 54$} & \multicolumn{3}{|c|}{$51 / 53$} & \multicolumn{3}{|c|}{$52 / 41$} \\
\hline
\end{tabular}




\section{Plantar Pressure Measurement}

Children's plantar pressure was measured by Footscan pressure plate (one meter plate, RSscan Int., Belgium). The scanning frequency of this system is $250 \mathrm{~Hz}$, pressure sensor density is $4 / \mathrm{cm}^{2}$, and the range of measure is $0-200 \mathrm{~N} / \mathrm{cm}^{2}$. A two-step initial protocol was performed by the children and they were guided to walk with their selected speed through the pressure plate which was located in the middle of six-meter-long track. The protocol of twosteps has been proved to be effectively reducing the times of trial and at the same time to improve the repeatability of the gait [14]. Before the measurement, a subject whose body weight was known was guided to walk through the plate to finish the calibration procedure; then three to five minutes warm up was provided. Three successful measures for each side of foot were also required.

\section{Data Processing}

Regions of plantar pressure were divided by Footscan software into ten parts (Figure 1): hallux, toes 2-5, the first to fifth metatarsal head (1st to 5th $\mathrm{MTH})$, mid foot (MF), medial heel (MH) and lateral heel (LH). Then parameters of peak pressure (PP) $\left(\mathrm{N} / \mathrm{cm}^{2}\right)$, pressure time integral $(\mathrm{PTI})\left(\mathrm{S}^{*} \mathrm{~N} / \mathrm{cm}^{2}\right)$ and contact area (CA) $\left(\mathrm{cm}^{2}\right)$ were selected out for analysis. Furthermore, a unitary processing for CA and $\mathrm{PTI}$ is required for inter-subjects contrast. Relative CA (CArel) $=100 \times(C A(X i) / \Sigma C A(X i))$; relative PTI (PTIrel) $=100 \times(\mathrm{PTI}(\mathrm{Xi}) / \Sigma \mathrm{PTI}(\mathrm{Xi}))$, where $\mathrm{Xi}$ indicates one of plantar regions. In addition, PTIrel has been proved to be an effective way to reduce the influence of weight, and it has been adopted in many research studies [2].

\section{Măsurarea presiunii plantare}

Presiunea plantară la copii a fost măsurată utilizând placa de presiune Footscan (placă de un metru, RSscan Int., Belgia). Frecvenţa de scanare a acestui sistem este de $250 \mathrm{~Hz}$, densitatea senzorului de presiune este de $4 / \mathrm{cm}^{2}$, iar domeniul de măsurare este de $0-200 \mathrm{~N} / \mathrm{cm}^{2}$. Copiii au urmat un protocol iniţial în doi paşi, apoi au fost îndrumaţi să meargă cu o viteză la alegere pe placa de presiune situată în centrul unei piste lungi de şase metri. Protocolul în doi paşi a redus în mod eficient durata testului şi, în acelaşi timp, a îmbunătăţit repetabilitatea mersului [14]. Înainte de efectuarea măsurătorii, un subiect cu greutate cunoscută a fost îndrumat să meargă pe platformă pentru a finaliza procedura de calibrare; s-au alocat apoi de la trei până la cinci minute pentru încălzire. Au fost necesare trei măsurători reuşite pentru fiecare parte a piciorului.

\section{Prelucrarea datelor}

Regiunile presiunii plantare au fost împărţite cu ajutorul programului Footscan în zece părţi (Figura 1): halucele, degetele $2-5$, regiunea de la primul la al cincilea cap metatarsian (1-5 MTH), zona mediană a piciorului (MF), partea de mijloc a călcâiului (MH) şi părţile laterale ale călcâiului (LH). S-au selectat următorii parametri pentru analiză: presiunea maximă (PP) $\left(\mathrm{N} / \mathrm{cm}^{2}\right)$, integrala presiune-timp (PTI) $\left(\mathrm{S}^{*} \mathrm{~N} / \mathrm{cm}^{2}\right)$ şi zona de contact $(C A)\left(\mathrm{cm}^{2}\right)$. Mai mult, a fost necesară o prelucrare unitară a CA şi PTI pentru a stabili deosebirea dintre subiecţi. CA relativă $($ CArel $)=100 \times(C A(X i) / \Sigma C A$ $(\mathrm{Xi}))$; $\mathrm{PTI}$ relativă $(\mathrm{PT}$ |rel) $=100 \times(\mathrm{PTI}(\mathrm{Xi}) / \Sigma \mathrm{PTI}(\mathrm{Xi}))$, unde $X i$ indică una dintre regiunile plantare. În plus, PTIrel s-a dovedit a fi un mod eficient de a reduce influenţa greutăţii şi a fost adoptată în multe studii de cercetare [2]. 


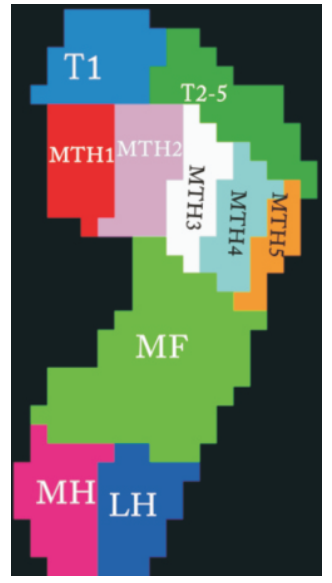

Figure 1. Ten masks model for plantar pressure analysis

Figura 1. Model cu zece zone pentru analiza presiunii plantare

\section{Statistical Analysis}

First of all, outcomes of independent $T$ test show that significant differences existed between left and right foot, hence only the right foot was selected out for data analysis. Further, $\mathrm{Q}-\mathrm{Q}$ plot was drawn and all the data was confirmed with the normal distribution. All variables in each age group were presented by mean \pm SD and error-bar plot was used to describe their changes with ages. The reliability of this study was assessed by coefficient of variance (CoV) and the intraclass correlation coefficient (ICC) $[15,16]$. The lower CoV, the better repeatability; whereas, when ICC $<0.5$, the reliability is poor, $0.5<$ ICC $<0.75$, the reliability is medium and ICC $>0.75$, reliability is good to excellent [17]. All statistical models were operated under the SPSS software (V16.0, SPSS Inc., USA) with the significance level of 0.05 and confidence interval (Cl) of $95 \%$.

\section{RESULTS AND DISCUSSIONS}

\section{Results of Plantar Pressure Distribution}

Peak Pressure

PP at T1 area was increasing with the age, especially after the age of seven, where PP raised rapidly, reaching $15.6 \%$ per year. While, children's PP at T2-5 changed irregularly during the ten year period (Table 2).

\section{Analiza statistică}

În primul rând, rezultatele testului T independent arată că au existat diferenţe semnificative între piciorul stâng şi piciorul drept; prin urmare, doar piciorul drept a fost selectat pentru analiza datelor. Mai mult, s-a trasat graficul Q-Q şi toate datele au fost confirmate $\mathrm{cu}$ distribuţia normală. S-au prezentat toate variabilele medii \pm abaterea standard din fiecare grupă de vârstă şi s-a utilizat diagrama cu bare de eroare pentru a descrie modificările apărute în funcţie de vârstă. Fiabilitatea acestui studiu a fost evaluată utilizând coeficientul de variaţie (CV) şi coeficientul de corelaţie intra-clasă (ICC) $[15,16]$. Cu cât este mai mic CV, cu atât mai bună este repetabilitatea; însă atunci când ICC $<0,5$, fiabilitatea este slabă, când $0,5<I C C<0,75$, fiabilitatea este medie, iar când ICC >0,75, fiabilitatea este bună spre excelentă [17]. Toate modelele statistice au fost prelucrate $\mathrm{cu}$ programul SPSS (V16.0, SPSS Inc, SUA), cu un nivel de semnificaţie de 0,05 şi intervalul de încredere $(\mathrm{Cl})$ de $95 \%$.

\section{REZULTATE ŞI DISCUTII}

\section{Rezultatele distribuţiei presiunii plantare}

Presiunea maximă

PP în zona T1 a crescut odată cu vârsta, mai ales după şapte ani, când PP a crescut rapid, ajungând la 15,6\% pe an. În zona T2-5, PP s-a modificat neregulat pe parcursul celor zece ani (Tabelul 2). 


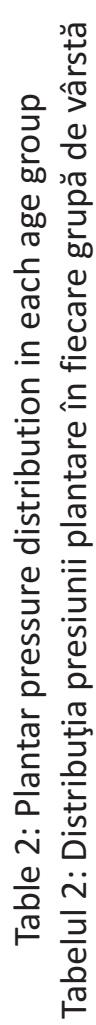

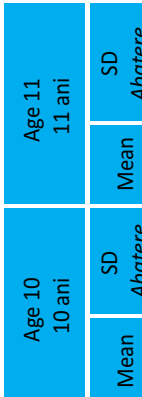

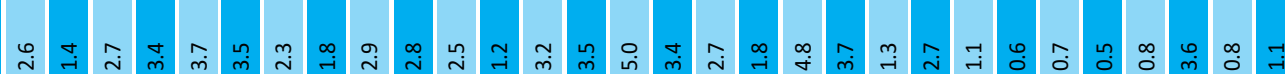

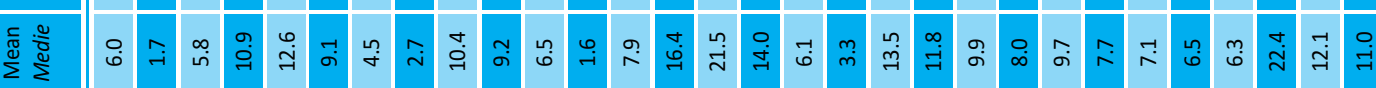

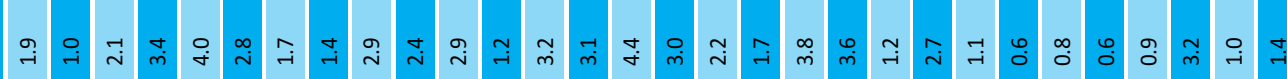

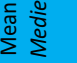

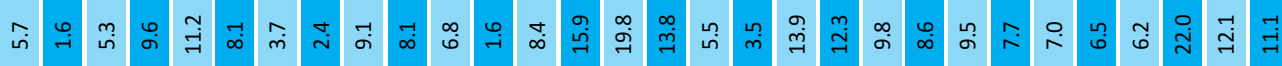

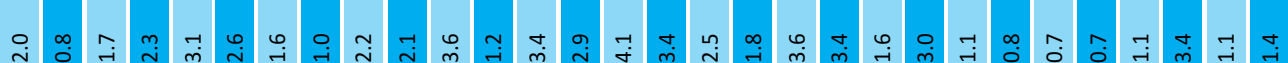

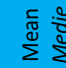

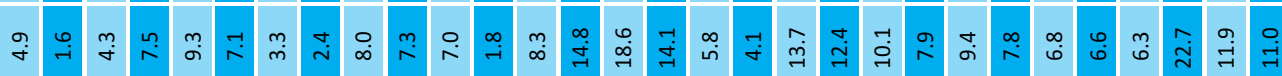

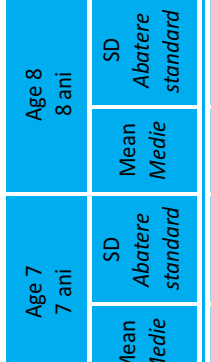

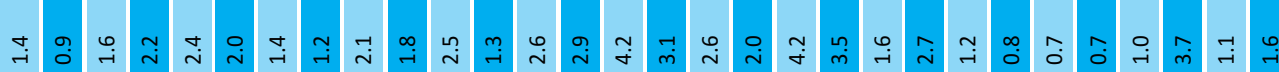

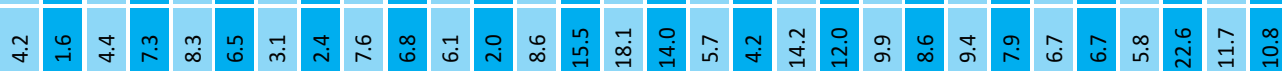

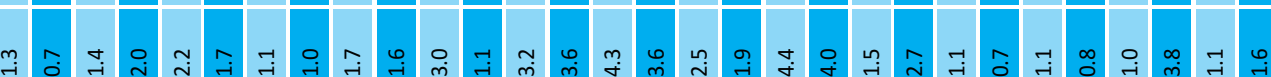

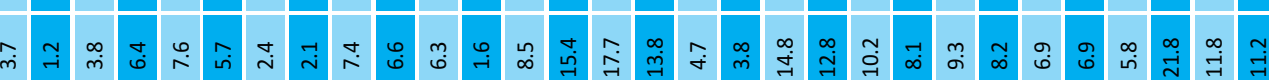

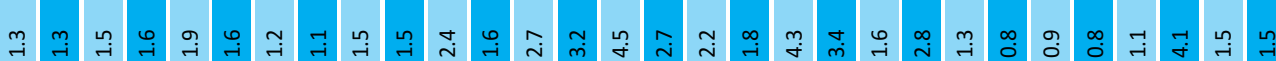

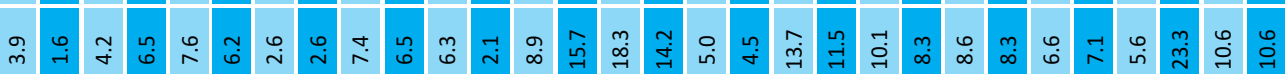

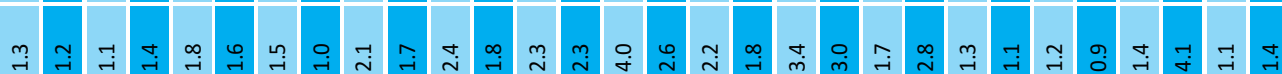
a 0 ก m

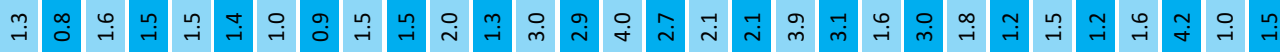
n $m$ m $\sum_{i}^{E}$

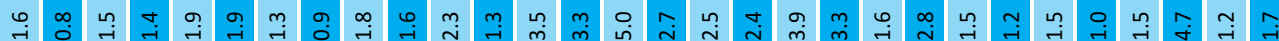

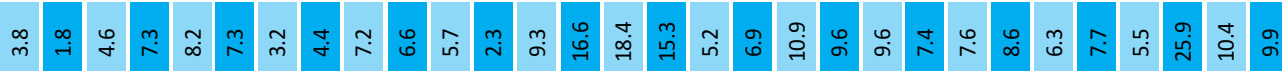

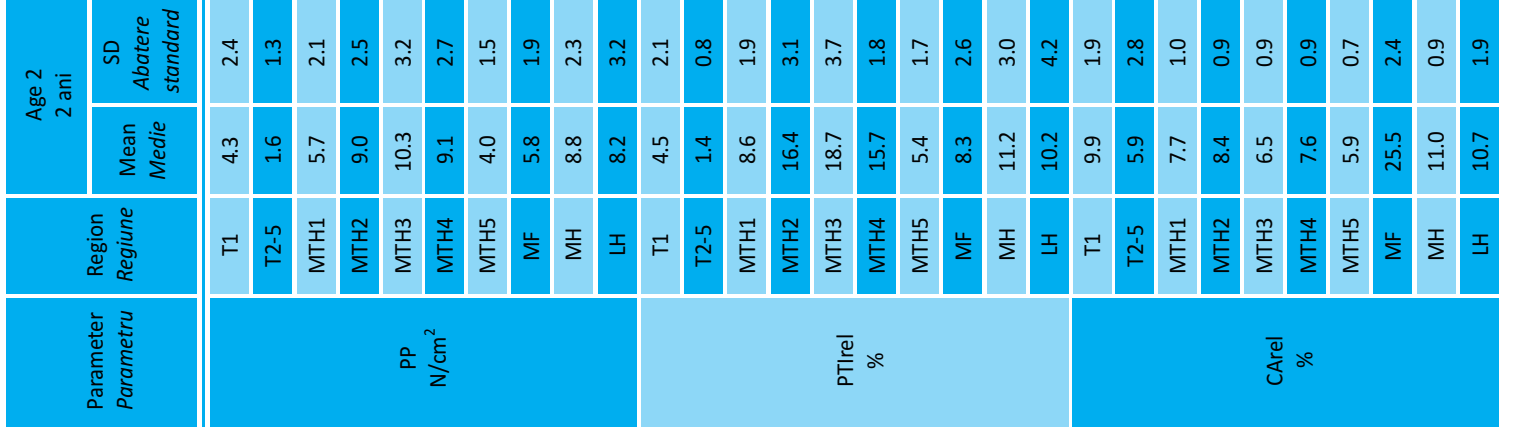


PP at MF declined gradually and its falling trend could be divided into two stages, two to seven and seven to 11 years old. During the first phase, PP decreased by $63.8 \%$ from $5.8 \pm 3.8 \mathrm{~N} / \mathrm{cm}^{2}$ at the age of two to $2.1 \pm 2.0 \mathrm{~N} / \mathrm{cm}^{2}$; within the second phase, PP at MF became stable (Figure 2A).
PP în zona MF a scăzut treptat, iar tendinţa de scădere a putut fi împărţită în două etape, de la doi la şapte ani şi de la şapte la 11 ani. În prima etapă, PP a scăzut cu $63,8 \%$, de la $5,8 \pm 3,8 \mathrm{~N} / \mathrm{cm}^{2}$ la doi ani până la $2,1 \pm 2,0 \mathrm{~N} / \mathrm{cm}^{2}$; în cea de-a doua etapă, PP în zona MF a devenit stabilă (Figura 2A).
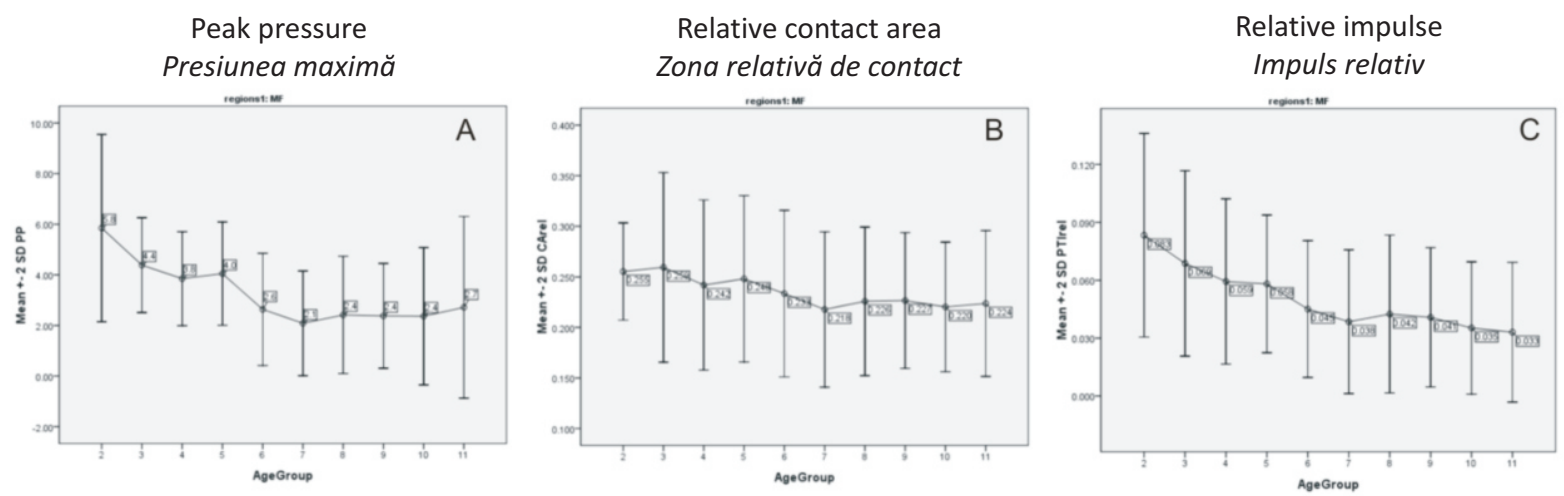

Figure 2. Correlation between the variable of PP (A), CArel (B) and PTIrel (C) and the age at the mid foot area

Figura 2. Corelaţie între variabilele PP (A), CArel (B) şi PTIrel (C) şi vârsta în zona mediană a piciorului

PP at MTH area demonstrated a "U" type trend: at first, PP significantly reduced between the age of two and three; and then falling speed became slow during the age between three to seven; finally, after the age of seven, PP tended to be stable (Table 2). The change of $\mathrm{PP}$ at $\mathrm{LH}$ and $\mathrm{MH}$ was similar, after a short period of decrease during the age of two to three, it increased steadily by $2.9 \mathrm{~N} / \mathrm{cm}^{2}$ in the whole nine years.

\section{Relative Contact Area}

Carel at T1 and T2-5 did not increase significantly with the age; whereas, that of MF reduced dramatically (Figure 2B). During the age between two to seven, CArel reduced from $25.5 \pm 4.8 \%$ at the age of two to $21.8 \pm 5.6 \%$ at the age of seven and then it decreased by less than $0.9 \%$ within the age between seven and 11 . Further, CArel at the medial (MTH1), central (MTH3) and lateral forefoot (MTH5) increased slowly with the age; while that of $\mathrm{MTH} 2$ and MTH4 decreased slightly. A general rising tendency could be found at the $\mathrm{MH}$ and LH (Table 2).
PP în zona MTH a prezentat o tendinţă de tip "U": la început, PP s-a redus semnificativ între vârsta de doi şi trei ani; apoi, între trei şi şapte ani, viteza de scădere a încetinit; în cele din urmă, după vârsta de şapte ani, PP a avut tendinţa de a se stabiliza (Tabelul 2). Modificarea PP în zonele LH şi MH a fost asemănătoare, după o scurtă perioadă de scădere între doi şi trei ani, a crescut în mod constant cu $2,9 \mathrm{~N} / \mathrm{cm}^{2}$ în toată perioada de nouă ani.

\section{Zona relativă de contact}

Carel în zonele T1 şi T2-5 nu a crescut semnificativ odată cu vârsta, în timp ce în zona MF s-a redus dramatic (Figura 2B). Între doi şi şapte ani, CArel s-a redus de la $25,5 \pm 4,8 \%$ la vârsta de doi ani, până la 21,8 $\pm 5,6 \%$ la şapte ani, apoi a scăzut cu mai puţin de $0,9 \%$ între şapte şi 11 ani. Mai mult decât atât, CArel în zonele mediană (MTH1), centrală (MTH3) şi laterală (MTH5) ale antepiciorului a crescut lent odată cu vârsta; în timp ce în zonele MTH2 şi MTH4 a scăzut uşor. S-a constatat o tendinţă generală de creştere în zonele $\mathrm{MH}$ şi LH (Tabelul 2). 


\section{Relative Pressure Time-Integral}

PTIrel at T1 region was similar with that of PP, but it increased more slowly. The mean growth rate was $0.2 \%$ /year. PTIrel at MF showed a dramatically falling tendency, it reduced by almost $60 \%$ from the age of two to 11 , where a $54 \%$ decrease happened at the stage of two to seven (Figure 2C). Besides, PTIrel at heel region was featured as vibrating and slow rising.

\section{Gender Variation}

Significant differences between boys and girls were observed, where PP and CArel of boys were significantly greater than those of girls, particularly at the MF area. The maximum difference of PP under MF region was found between the ages of six and eight, where boys' PP was higher than that of girls by 0.48 and $0.45 \mathrm{~N} / \mathrm{cm}^{2}(p=0.01)$, respectively. At the ages of three, four, eight and nine, the boys' CArel at MF area were significantly larger than that of girls by $4 \%(P=$ $0.001), 2.7 \%(P=0.02)$ and $1.4 \%(P=0.01)$ and $2.1 \%(P$ $=0.001$ ) individually. In addition, boys' PTIrel at MF was higher than that of girls in most age groups and significant differences were found at the age of three $(P=0.002)$ and four $(P=0.045)$. PTIrel at other foot regions existed significant gender differences within few age groups.

\section{Integrala relativă presiune-timp}

Valoarea PTIrel în zona T1 a fost asemănătoare cu cea a PP, dar a crescut mai lent. Viteza medie de creştere a fost de 0,2\%/an. PTIrel în zona MF a prezentat o tendinţă de scădere dramatică, reducându-se cu aproape $60 \%$ de la doi la 11 ani, iar o scădere de 54\% a avut loc între doi şi şapte ani (Figura 2C). În plus, PTIrel în regiunea călcâiului a prezentat oscilaţii şi o creştere lentă.

\section{Variaţia între sexe}

S-au observat diferenţe semnificative între băieţi şi fete, PP şi CArel fiind semnificativ mai mari la băieţi decât la fete, mai ales în zona MF. S-a constatat că diferenţa maximă între valorile PP sub zona MF se regăseşte între şase şi opt ani, valoarea PP la băieţi fiind mai mare decât la fete cu 0,48 , respectiv $0,45 \mathrm{~N} / \mathrm{cm}^{2}(p=$ $0,01)$. La vârstele de trei, patru, opt şi nouă ani, valorile CArel în zona MF la băieţi au fost semnificativ mai mari decât la fete, cu $4 \%(P=0,001), 2,7 \%(P=0,02)$ şi 1,4\% ( $P$ $=0,01)$ şi $2,1 \%(P=0,001)$ individual. În plus, PTIrel în zona MF la băieţi a fost mai mare decât la fete în majoritatea grupelor de vârstă şi s-au găsit diferenţe semnificative la vârsta de trei ani $(P=0,002)$ şi patru ani $(P=0,045)$. Au existat diferenţe semnificative între sexe în ceea ce priveşte valorile PTIrel în alte zone ale piciorului în cadrul câtorva grupe de vârstă.
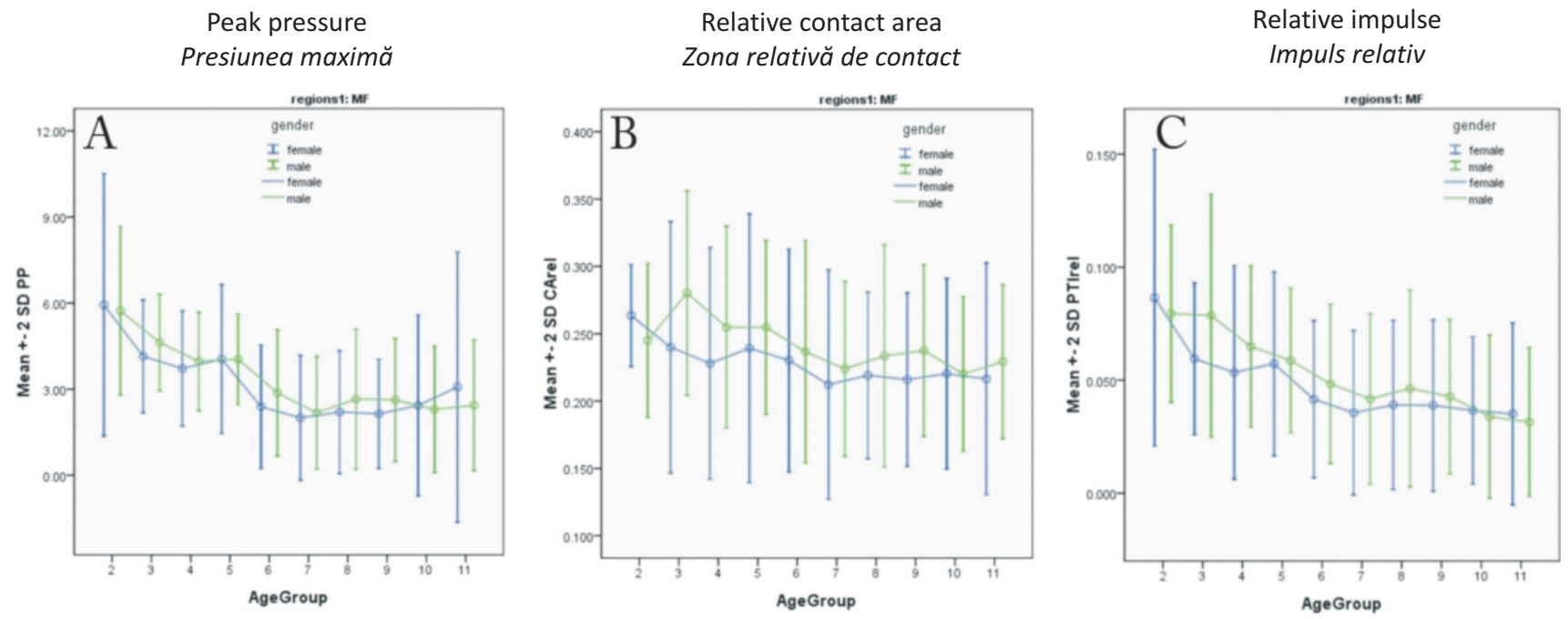

Figure 3. Gender differences of variables of PP, CArel and PTIrel at the mid foot area Figura 3. Diferenţe între sexe privind variabilele PP, CArel şi PTIrel în zona mediană a piciorului 


\section{Reliability Analysis}

A good to excellent ICCave was obtained for variables of PP, PTIrel and CArel (ICCave $=0.91>0.75$ for PP, $\mathrm{p}=0.000$; ICCave $=0.905>0.75$ for PTIrel, $\mathrm{p}=0.000$; ICCave $=0.96>0.75$ for CArel, $p=0.000)$; whereas, excepting CoV of PTIrel which received a higher CoV value, those of PP and CArel were reasonable ( $\mathrm{CoV}=$ $10.1 \%$ for PP CoV $=10.1 \%$ for CArel). Meanwhile, ICCave of PTIrel improved with the age and the best $r^{2}$ was recorded $(p=0.004)$; whereas, moderate to good linear correlations were also obtained for PP and CArel $\left(r^{2}=0.623, p=0.011\right.$ for PP; $r^{2}=0.522, p=0.028$ for CArel).

\section{Discussions}

This study measured the plantar pressure of 895 healthy Chinese children aged between two and 11; and then features of plantar pressure distribution of Chinese children were thoroughly investigated. Our outcomes show that plantar pressure was increasing with the foot development in the most foot regions, except the mid foot area; besides, although gender differences existed in all foot regions and for the boys a higher pressure and a larger contact area were recorded, significant differences were only found in a few age groups. At last, reliability analysis demonstrated that results of all three parameters were reliable and repeatable; further the reliability of all variables was promoting with the age.

Our outcome showed that PP and PTIrel at T1 increased by $39.5 \%$ and $44.4 \%$ during the ten years period and the largest PP and PTIrel was $6.0 \mathrm{~N} / \mathrm{cm}^{2}$ and $6.8 \%$ individually; whereas, they were decreasing sharply under the mid foot and $53.4 \%$ and $60.2 \%$ of deduction were obtained for PP and PTI, respectively. Those dramatic developments happened in the first five to seven years since independent walking; within this period, foot structure and gait pattern became fullfledged.

However, variations existed between our study and the current literature. In terms of pressure distribution, Hallemans et al. [18] followed and measured the children's foot plantar pressure in a successive five months since their independent walking, their outcomes of pressure distribution demonstrated that peak pressures were highly variable

\section{Analiza fiabilităţii}

S-a obţinut o valoare ICCave bună spre excelentă pentru variabilele PP, PTIrel şi CArel (ICCave $=0,91>$ 0,75 pentru $\mathrm{PP}, \mathrm{p}=0,000$; ICCave $=0,905>0,75$ pentru PTIrel, $p=0,000$; ICCave $=0,96>0,75$ pentru CArel, $p=$ $0,000)$; în timp ce, cu excepţia CV a PTIrel care a avut o valoare mai mare, valorile PP şi CArel au fost rezonabile ( $C V=10,1 \%$ pentru PP; $C V=10.1 \%$ pentru CArel). Între timp, valoarea ICCave a PTIrel s-a îmbunătăţit cu vârsta, înregistrându-se cea mai bună valoare $r^{2}(p=0,004)$; $s$ au obţinut, de asemenea, corelaţii liniare bune pentru PP şi CArel $\left(r^{2}=0,623, p=0,011\right.$ pentru PP; $r^{2}=0,522, p=$ 0,028 pentru CArel).

\section{Discuţii}

În cadrul acestui studiu s-a măsurat presiunea plantară la 895 copii sănătoşi din China cu vârstele între doi şi 11 ani; apoi s-au investigat în detaliu caracteristicile distribuţiei presiunii plantare la aceşti copiii. Rezultatele obţinute indică faptul că presiunea plantară creşte odată cu dezvoltarea piciorului în majoritatea zonelor, cu excepţia zonei mediane a piciorului; în plus, deşi au existat diferenţe între sexe în toate zonele piciorului şi s-au înregistrat o presiune mai ridicată şi o zonă de contact mai mare la băieţi, s-au constatat diferenţe semnificative doar la câteva grupe de vârstă. În cele din urmă, analiza fiabilităţii a demonstrat că rezultatele tuturor celor trei parametri au fost de încredere şi repetabile; mai mult, fiabilitatea tuturor variabilelor s-a îmbunătăţit odată cu vârsta.

Rezultatele obţinute au demonstrat că PP şi PTIrel în zona T1 au crescut cu 39,5\% şi 44,4\% pe parcursul celor zece ani, iar cele mai mari valori PP şi PTIrel au fost 6,0 N/cm $\mathrm{cm}^{2}$ şi 6,8\% individual; acestea au scăzut brusc în zona mediană a piciorului, obţinându-se scăderi de $53,4 \%$ şi 60,2\% pentru PP, respectiv PTI. Aceste dezvoltări dramatice au avut loc în perioada de la cinci până la şapte ani din momentul în care au început să meargă independent, în această perioadă structura piciorului şi mersul dezvoltându-se complet.

Cu toate acestea, au existat variaţii între studiul nostru şi literatura actuală. În ceea ce priveşte distribuţia presiunii, Hallemans şi colab. [18] au urmărit şi au măsurat presiunea plantară la copii timp de cinci luni succesive din momentul în care au început să meargă independent, iar rezultatele lor privind distribuţia presiunii au demonstrat că presiunea maximă a variat foarte mult între diferite teste ale 
between different trials of the same individual and the largest was under the heel $\left(6.58 \mathrm{~N} / \mathrm{cm}^{2}\right)$, and then followed by the central $\left(5.86 \mathrm{~N} / \mathrm{cm}^{2}\right)$ and medial $(4.62$ $\left.\mathrm{N} / \mathrm{cm}^{2}\right)$ metatarsal heads, first toe $\left(4.10 \mathrm{~N} / \mathrm{cm}^{2}\right)$; however, pressures underneath the mid foot were relatively large $\left(4.24 \mathrm{~N} / \mathrm{cm}^{2}\right)$. Similarly, Bosch et al. [10, 11] conducted a research aiming at rebuilding a normative plantar pressure distribution of German children. They recruited nearly 63 healthy children and tracked their foot development for four years. According to every six month's foot inspection and measure, features of foot development were explained. Bosch reported the dynamic foot loading of the total foot was increased by $190 \%$; while, a decrease by $63 \%$ for the relative maximum force under the mid foot was also obtained. Although a similar tendency was found in our study, the change in current study was more significant than that of ours. The variation could be due to the fact that Hallemans and Bosch's study recruited toddlers starting to walk. Within the first six to 12 months of independent walking, toddlers' feet grew the fastest.

In terms of hallux (T1) area, Hallemans et al. [18] also described a hallux varus when the child started to walk; then the hallux gradually shifted to a normal angle. The state of hallux varus on the one hand increased the contact area of hallux region, which is beneficial for the foot posture control; on the other hand, it was helpful for power generation at the heeloff phase. Thereby, a higher pressure and larger contact area could be obtained in this area. However, in our study, a hallux varus was not observed, so we assumed that before the age of two, the toddler had finished the general foot development.

In terms of MF region, current knowledge approved that MF area filled with fat pad in the early children's independent walking, and this structure played an important role in the toddler's early walking $[19,20]$. Hence, a relatively larger pressure was usually found in this area [2]. As the development procedure continued, this fad pad gradually diminished and formed the foot longitudinal arch [10, 19]. Thereby both the pressure and contact area at mid foot decreased dramatically. Our results also proved the above finding. However, in our study, PP, PTIrel and CArel declined obviously before the age of seven and after the age of seven, all three variables remained aceluiaşi individ, cea mai mare valoare înregistrându-se sub călcâi $\left(6,58 \mathrm{~N} / \mathrm{cm}^{2}\right)$, urmată de capetele metatarsiene central $\left(5,86 \mathrm{~N} / \mathrm{cm}^{2}\right)$ şi median $(4,62$ $\left.\mathrm{N} / \mathrm{cm}^{2}\right)$, primul deget $\left(4,10 \mathrm{~N} / \mathrm{cm}^{2}\right)$; cu toate acestea, presiunile de sub zona mediană au fost relativ mari $\left(4,24 \mathrm{~N} / \mathrm{cm}^{2}\right)$. În mod similar, Bosch şi colab. $[10,11]$ au efectuat un studiu cu scopul de a reconstrui distribuţia presiunii plantare normative la copiii din Germania. Aceştia au recrutat aproximativ 63 de copii sănătoşi şi au urmărit dezvoltarea piciorului timp de patru ani. În urma inspecţiei şi măsurătorilor efectuate o dată la şase luni, s-au descris caracteristicile dezvoltării piciorului. Bosch a raportat o creştere de $190 \%$ a încărcării piciorului în dinamică faţă de piciorul luat în ansamblu, şi o scădere cu $63 \%$ a forţei maxime relative în zona mediană a piciorului. Deşi s-a observat o tendinţă asemănătoare în studiul nostru, modificarea apărută în studiul menţionat a fost mai semnificativă decât cea din studiul nostru. Variaţia se poate datora faptului că Hallemans şi Bosch au recrutat pentru studiu copii care de-abia începeau să meargă. În primele 6-12 luni de mers independent, picioarele copiilor cresc cel mai repede.

În zona halucelui (T1), Hallemans şi colab. [18] au relatat apariţia hallux varus atunci când copilul a început să meargă; apoi halucele a revenit treptat întrun unghi normal. Starea de hallux varus a mărit, pe de o parte, zona de contact din regiunea halucelui, lucru benefic pentru controlul poziţiei piciorului; pe de altă parte, a fost utilă pentru generarea energiei în faza de ridicare a călcâiului de pe sol. În acest fel, în această zonă obţinut o presiune mai ridicată şi o zonă de contact mai mare. Cu toate acestea, în studiul nostru nu am observat hallux varus, aşadar am presupus că faza de dezvoltare a piciorului copilului s-a încheiat înainte de vârsta de doi ani.

În ceea ce priveşte zona MF, cunoştinţele actuale au confirmat că zona MF este acoperită de grăsime în faza timpurie de mers independent şi această structură are o influenţă considerabilă asupra mersului copilului în acea perioadă $[19,20]$. Prin urmare, în această zonă s-a constatat în general o presiune relativă mai mare [2]. Pe măsură ce dezvoltarea continuă, acel strat de grăsime se diminuează treptat şi formează bolta longitudinală a piciorului $[10,19]$. Astfel, atât presiunea, cât şi zona de contact în regiunea mediană a piciorului au scăzut dramatic. Rezultatele obţinute au confirmat constatarea menţionată mai sus. Cu toate acestea, în studiul nostru, PP, PTIrel şi CArel au scăzut în mod evident înainte de vârsta de şapte ani, iar după această vârstă, toate variabilele au rămas relativ stabile. Acest fenomen 
relatively stable. This phenomenon was varied with current literature which reported that the foot arch developed completely before the age of six [20]. This variation could be explained by the diversity of children's growth [7].

In terms of MTH region, Bosch et al. [10] pointed out that PP and CArel at medial forefoot increased significantly with the age; whereas, our results indicated that the central of MTH $(\mathrm{MTH} 2,3,4)$ was recorded with the highest PP and PTIrel. In the early independent walking, medial forefoot assisted the hallux in load accepting; as the transverse arch at forefoot became mature, the central forefoot played a key role in pressure acceptance. This developing map road could explain the variation between our study and Bosch's.

Moreover, our study also explored gender difference in terms of plantar pressure distribution and our outcomes indicated that the main differences were focused on MF area. Our results were approved by Bosch's investigation [11]. They suggested that body weight grew faster in boys than in girls, and this main variation contributed to the larger CArel and PP at mid foot.

Although this study described foot development of Chinese healthy children in terms of plantar pressure distribution, two limitations existed in this study and should be comprehended with caution: 1 . healthy subjects recruited in this study were from southwest of China, Sichuan province, so our outcomes might differ from subjects of other districts; 2 . since self-selected walking speed was performed, by which the dynamic foot pattern might be affected, different walking speeds could affect the validity of the within-groups comparison. The future work will continue to investigate the feature of foot biomechanics of healthy Chinese children in terms of gait balance and gait cycle.

\section{CONCLUSIONS}

Overall, our study provided a normative plantar pressure distribution of healthy Chinese children and those findings could be used in the abnormal feet evaluation, in the diagnosis of children's foot diseases and in designing health shoes for Chinese children. variază în literatura de specialitate, care raportează că bolta piciorului se dezvoltă complet înainte de vârsta de şase ani [20]. Această variaţie poate fi explicată prin diferenţele de creştere [7].

În ceea ce priveşte zona MTH, Bosch şi colab. [10] au indicat faptul că PP şi CArel în zona de mijloc a antepiciorului au crescut semnificativ odată cu vârsta; însă rezultatele noastre au arătat că în zona centrală a MTH (MTH 2, 3, 4) s-au înregistrat cele mai mari valori pentru PP şi PTIrel. În faza timpurie a mersului independent, zona de mijloc a antepiciorului a preluat o parte din încărcătura asupra halucelui; pe măsură ce bolta transversală în zona antepiciorului s-a dezvoltat, zona centrală a antepiciorului a jucat un rol decisiv în preluarea presiunii. Acest proces de dezvoltare ar putea explica variaţia dintre studiul nostru şi cel al lui Bosch.

Mai mult decât atât, studiul nostru a explorat şi diferenţele între sexe cu privire la distribuţia presiunii plantare şi rezultatele obţinute au indicat faptul că principalele diferenţe se regăsesc în zona MF. Rezultatele noastre au fost confirmate de investigaţia lui Bosch [11]. Acesta a sugerat că băieţii iau în greutate mai repede decât fetele, iar această variaţie principală a contribuit la valorile mai mari ale CArel şi PP în zona mediană a piciorului.

Deşi acest studiu a descris dezvoltarea piciorului la copii sănătoşi din China cu referire la distribuţia presiunii plantare, au existat două limitări, care trebuie înţelese cu grijă: 1. subiecţii sănătoşi recrutaţi pentru acest studiu au provenit din sud-vestul Chinei, provincia Sichuan, aşadar rezultatele noastre pot diferi de cele obţinute cu alţi subiecţi din alte regiuni; 2 . întrucât viteza de mers, care poate afecta tiparul dinamic al piciorului, a fost la libera alegere a subiectului, vitezele de mers diferite ar putea influenţa validitatea comparaţiei între grupe. Lucrările viitoare vor continua să investigheze caracteristicile biomecanicii piciorului la copiii sănătoşi din China cu privire la echilibrul mersului şi ciclul de mers.

\section{CONCLUZII}

Per ansamblu, studiul nostru a oferit o distribuţie normativă a presiunii plantare la copiii sănătoşi din China, iar rezultatele obţinute ar putea fi utilizate la evaluarea clinică a picioarelor cu probleme, la diagnosticarea bolilor de picioare la copii şi la conceperea încălţămintei ortopedice pentru copiii din China. 


\section{Acknowledgement}

The author would like to thank the financial support from Funding of Sichuan University (2014SCU11029).
Mulţumiri

Autorul doreşte să mulţumească Universităţii Sichuan pentru sprijin financiar (2014SCU11029).

\section{REFERENCES}

1. Brenière, Y., Bril, B., Exp. Brain Res., 1998, 121, 3, 255-262.

2. Hallemans, A., D'Août, K., De Clercq, D., Aerts, P., Foot Ankle Int., 2003, 24, 5, 444-453.

3. Walther, M., Herold, D., Sinderhauf, A., Morrison, R., Foot Ankle Surg., 2008, 180-189.

4. Lythgo, N., Wilson, C., Galea, M., Gait Posture, 2009, 30, 4, 502-506.

5. Sutherland, D.H., Olshen, R., Cooper, L., Woo, S. L. Y., J Bone Joint Surg., 1980, 62, 3, 336-353.

6. Mickle, K.J., Steele J.R., Munro B.J., Int. J. Pediatr. Obes., 2006, 1, 3, 183-188.

7. Phyllis, B., Eveleth, J.M.T., Worldwide variations in human development, Cambridge University Press, UK, 1976.

8. De Cock, A., Willems, T., Witvrouw, E., De Clercq, D., Gait Posture, 2008, 669-675.

9. Hughes, J., Acta Orthopaedica Belgica, 1993, 59, 1, 10-6.

10. Bosch, K., Gerss, J., Rosenbaum, D., Gait Posture, 2007, 26, 2, 238-247.

11. Bosch, K., Gerss, J., Rosenbaum, D., Gait Posture, 2010, 32, 4, 564-571.

12. Alvarez, C., De Vera, M., Chhina, H., Black, A., Gait Posture, 2008, 28, 2, 309-15.

13. Hennig, E.M., Staats, A., Rosenbaum D., Foot Ankle, 1994, 15, 1, 35-40.

14. Bus, S.A., de Lange, A., Clin. Biomech., 2005, 20, 9, 892-899.

15. Hopkins, W.G., Sports Med., 2000, 30, 1, 1-15.

16. Ramanathan, A.K., Kiran, P., Arnold, G. P., Wang, W., Abboud, R. J., Foot Ankle Surg, 2010, 16, 2, 70-3.

17. Leslie Gross, P., Watkins, M.P., Foundations of Clinical Research: Applications to Practice, Appleton and Lange, Connecticut, 1993.

18. Hallemans, A., De Clercq, D., Van Dongen, S., Aerts, P., Gait Posture, 2006, 23, 2, 142-8.

19. Gould, N., Moreland, M., Alvarez, R., Trevino, S., Fenwick, J., Foot Ankle, 1989, 9, $5,5$.

20. Walther, M., Herold, D., Sinderhauf, A., Morrison, R., Foot Ankle Surg, 2008, 14, 4, 180-9.

Article received/Data primirii articolului: 02.06.2014

Accepted/Acceptat la data: 30.07.2014 